Chirurgia (2020) 115: 635-642

No. 5, September - October

Copyright@ Celsius

http://dx.doi.org/10.21614/chirurgia.115.5.635

\title{
Publication Activity on Liver Transplantation from Southeastern European Countries: A Bibliometric Analysis
}

\author{
Anna Mrzljak ${ }^{1,2^{*}}$, Rafaela Novak², Danko Mikulic ${ }^{3}$ \\ 'Department of Medicine, Merkur University Hospital, Zagreb, Croatia \\ ${ }^{2}$ School of Medicine, University of Zagreb, Croatia \\ ${ }^{3}$ Department of Surgery, Merkur University Hospital, Zagreb, Croatia
}

*Corresponding author:

Anna Mrzljak MD, PhD

Department of Medicine

Merkur University Hospital

Zajceva 19, 10000 Zagreb

School of Medicine

University of Zagreb

Salata 3b, 10000 Zagreb, Croatia

E-mail: anna.mrzljak@mef.hr
Received: 18.05 .2020

Accepted: 20.07 .2020

\section{Rezumat}

Activitatea publicistică având ca subiect transplantul hepatic din țările din sud-estul Europei: o analiză bibliometrică

Context: Transplantul hepatic a devenit un domeniu cu o vastă activitate publicistică; cu toate acestea, există foarte puține cercetări asupra publicatiilor care tratează transplantul hepatic în țările din sud-estul Europei (SEE). Ințelegerea factorilor care influențează decizia publicării este esențială pentru ghidarea/orientarea cercetării şi pentru promovarea publicării studiilor de înaltă calitate.

Metode: S-a realizat o analiză bibliometrică a studiilor publicate în PubMed despre experiența clinică a transplantului hepatic din 11 țări din regiunea SEE înainte de 2020. Datele au inclus numărul de publicatiii, citări, factorii (cumulativi) de impact ai publicațiilor ştiințifice (IF), sexul şi profesia primului autor/autorului principal. Rezultate: 188 de publicatii corespund criteriilor de includere. 25,5\% din lucrări au fost publicate în reviste fără IF. Cele mai multe lucrări provin din Grecia $(43,6 \%, 199.663$ IF), România (29,3\%, 60,695 IF) şi Croația (16\%, 45,645 IF). În primele trei țări, primii autori au fost predominant medici bărbați. Autori principali au fost, de asemenea, în mare parte bărbați (63,3-88\%), cu profesii diferite de la o țară la alta $(\mathrm{p}=0,008)$.

Concluzie:În general, activitatea publicistică privind transplantul hepatic din țările SEE este modestă. Autorii din Grecia sunt cei mai productivi din regiune. Un număr ridicat de transplante hepatice nu se traduce neapărat într-un număr ridicat de articole publicate. Societățile de transplant hepatic din țările SEE ar trebui să găsească solutiii pentru a intensifica cercetarea şi publicarea în domeniu. 
Cuvinte-cheie: publicare, transplant de ficat, analiză bibliometrică, sud-estul Europei, sex, autor

\section{Abstract}

Background:Liver transplantation (LT) has become a field with rich publication activity; however, there is a paucity of research regarding LT publications from southeastern European (SEE) countries. Understanding the factors that influence the publication output is essential to direct the research and to promote the publication of high-quality papers.

Methods: A bibliometric analysis was performed in PubMed for articles published on LT-related clinical experience from 11 countries from the SEE region before 2020. Data included the number of publications, citations, journal (cumulative) impact factors (IFs) and first/senior author gender and profession.

Results: 188 publications fitted the inclusion criteria. $25.5 \%$ of papers were published in journals without IFs. Most papers came from Greece $(43.6 \%, 199.663 \mathrm{IFs})$, Romania $(29.3 \%, 60.695 \mathrm{IFs})$ and Croatia $(16 \%, 45.645 \mathrm{IFs})$. In the top three countries, first authors were dominantly male physicians. Senior authors were also mostly male (63.3-88\%), with varying professions depending on the country $(\mathrm{p}=0.008)$.

Conclusion: The overall LT publication activity from the SEE countries is modest. The authors of Greece are the most productive in the region. The high liver LT activity does not necessarily translate into high publication output. LT communities in the SEE countries should find solutions on how to increase research and publication output.

Key words: publication, liver transplantation, bibliometric analysis, southeastern Europe, gender, author

\section{Introduction}

During the past few decades, liver transplant (LT) has evolved into an almost routine procedure with good survival outcomes in many European countries. However, there are still significant disparities in transplantation activity especially in southeastern Europe (SEE) where some Balkan countries (Albania, Bosnia and Herzegovina, Kosovo, Montenegro, North Macedonia) are lagging behind the international averages (Table 1). On the other hand, in the same region, Croatia has one of the highest LT rates in the world according to the International Registry on Organ Donation and Transplantation, estimated between 27.35-32.2 per million population (pmp) (20142019) (Table 1)(1).

Publications are the most commonly used instrument through which the results from a specific field are conveyed globally (2). Such is also the case in LT, where the evolution in the field has been reflected by numerous manuscripts published in national and international journals, varying from case reports to systematic reviews. In addition, publications are principal instruments of academic recognition and promotion for the researchers and institutions (3). Factors influencing publication output in the mainly Englishbased medical journals are numerous, though the research funding and English proficiency of the authors have been identified as the important determinants (4). The quantification of publication activity of a certain country shows the country's development in research status in a specific field. However, little is known about the contribution of SEE medical researchers to the scientific field of LT. This bibliometric analysis was conducted to quantify the contributions reporting on the national experience with LT from the SEE region. 


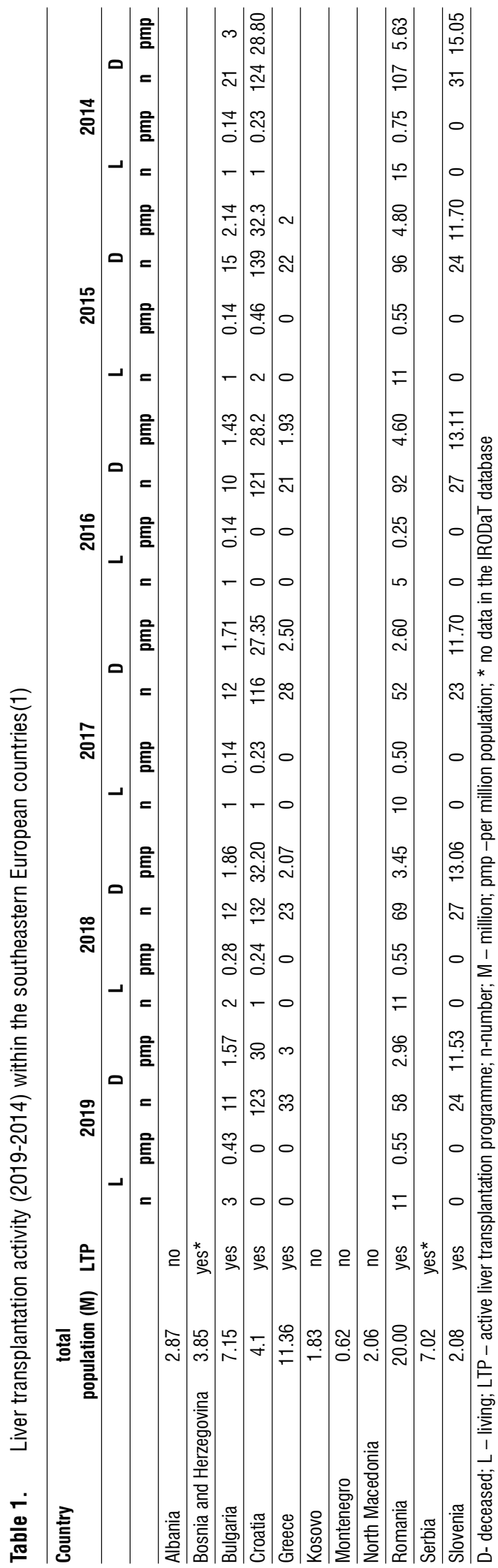

Methods

A bibliometric analysis was performed in PubMed in the period from $15^{\text {th }}$ to $19^{\text {th }}$ of April 2020 for articles published on LT clinical experience from the SEE region before 2020, using a search strategy: ((("Liver Transplantation" (Mesh)) OR (liver(tiab) OR hepatic(tiab))) AND (transplant*(tiab) OR graft*(tiab))) AND "country" - one of the 11 countries in the SEE/Balkan region; Albania, Bulgaria, Bosnia and Herzegovina, Croatia, Greece, Kosovo, Montenegro, North Macedonia (former Macedonia), Romania, Serbia, Slovenia and additionally former Yugoslavia (Fig. 1). The inclusion of articles was based on the following criteria: the article had to provide an abstract in English published in PubMed, and consist of clinical data with at least one (paediatric or adult) report on LT or LT-related issue(s) from the country of origin. The articles in which domicile authors reported clinical experience from a different country(ies) only, were excluded. Non-clinical studies, including animal studies, review articles, meta-analysis and books, were excluded. All articles were screened independently by two authors, by manually checking the title, author information and abstract in PubMed. Once a comprehensive list of abstracts was retrieved and reviewed, any paper appearing to meet the inclusion criteria was reviewed in full.

For each paper, the Journal Impact Factor (IF) of the respective journal by InCites Journal Citation Reports of Clarivate Analytics (2018), and the number of citations for each article from Web of Science (Databases) were determined between $15^{\text {th }}$ to $19^{\text {th }}$ of April 2020. The total number of publications per country was counted. The total number of papers was divided by the number of the country's inhabitants to obtain a publication per inhabitant ratio. In addition, the data containing the first and the senior author's gender and profession were collected. The profession was extracted from the author's information section and related to the stated department. If numerous departments 
Figure 1. Search strategy using the PubMed database for publication on liver transplantation in Southeastern European countries until 2020. The results for induced articles and screened articles are displayed for Albania, Bulgaria, Bosnia and Herzegovina, Croatia, Greece, Montenegro, North Macedonia (formerly Macedonia), Romania, Serbia, Slovenia in addition to the availability of national liver transplantation programs (liver icon). The results for Kosovo (0/1) and former Yugoslavia (0/7) are not displayed on the map

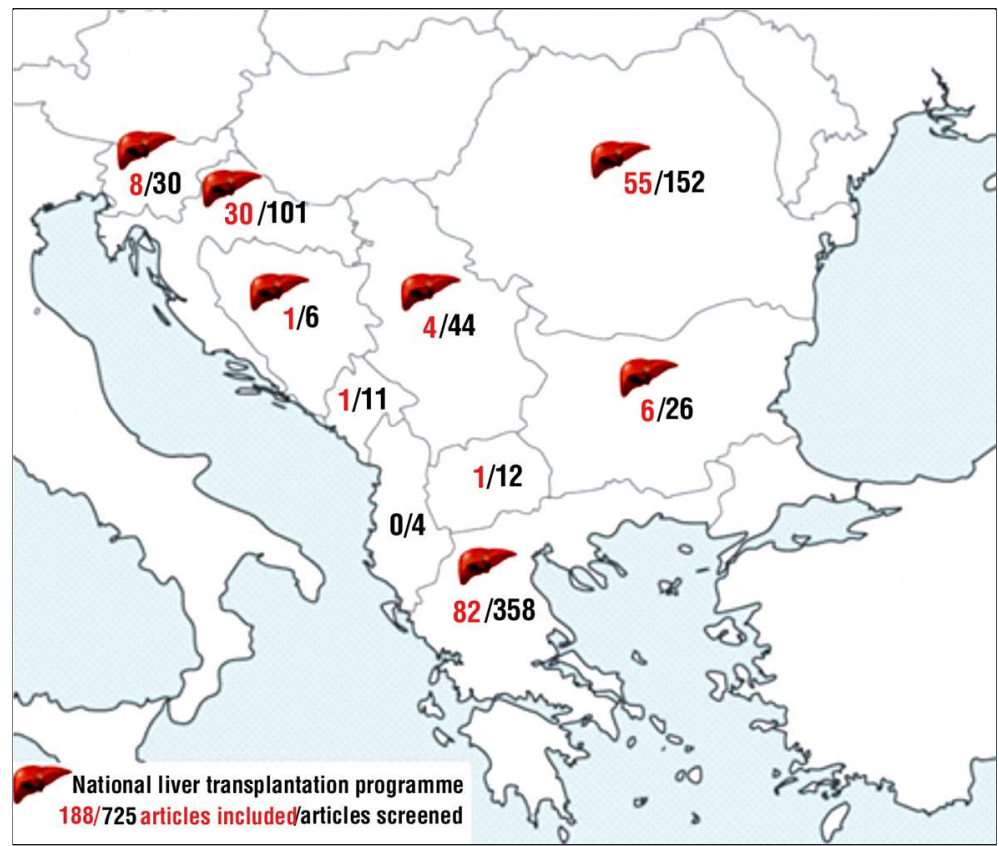

were listed, the profession was appointed to the first department listed. Statistical analysis was performed using MedCalc. Categorical data are presented as numbers (percentages). Differences between the groups were tested using Chi-square - and Fischer's exact test (categorical variables). The level of statistical significance was set at $p<0.05$ and all tests were two-tailed.

\section{Results}

Until 2020, our search strategy identified 752 publications from 11 SEE countries. After the application of inclusion and exclusion criteria, 188 publications remained. All 11 countries, except Albania and Kosovo, had at least one publication fitting the above criteria (Fig. 1). The majority of the countries had a low number of publications (8 and less) with Greece having the highest number of publications comprising $43.6 \%$ of all publication activity from the SEE region in the analysed time-frame. The LT-related publications in the SEE countries are presented in Table 2.

When publication per inhabitant ratio was analysed, Croatia and Greece were the top two countries within the Balkan region with 7.32

Table 2. Publications on national liver transplantation activity from 9 SEE countries until 2020

\begin{tabular}{lccccc}
\hline Country & n publications & percentage & n per million population & cumulative IF & total citations \\
\hline Bosnia and Herzegovina & 1 & 0.5 & 0.26 & 0 & 2 \\
\hline Bulgaria & 6 & 3.2 & 0.84 & 9.896 & 32 \\
\hline Croatia & 30 & 16.0 & 7.32 & 45.645 & 105 \\
\hline Greece & 82 & 43.6 & 7.22 & 199.663 & 1014 \\
\hline North Macedonia & 1 & 0.5 & 0.49 & 0 & 0 \\
\hline Montenegro & 1 & 0.5 & 1.61 & 1.153 & 0 \\
\hline Romania & 55 & 29.3 & 2.75 & 60.695 & 358 \\
\hline Serbia & 4 & 2.1 & 0.57 & 0.493 & 10 \\
\hline Slovenia & 8 & 4.3 & 3.37 & 49.172 & 70 \\
\hline total & 188 & 100 & 3.84 & 366.717 & 1591 \\
\hline
\end{tabular}


and 7.22 publications pmp, respectively. The number of publications per million inhabitants per country is given in Table 2.

Forty-eight publications (25.5\%) were published in journals without impact factor (IF). The country with the highest cumulative IF was Greece (199.663), while Bosnia and Herzegovina and North Macedonia published only in journals without IFs. All cumulative journal impact factors (JIF) are listed in Table 2. Greece also had the highest number of citations (1014) among study nations. The cumulative numbers of citations per country are presented in Table 2 .

First reports on LT-related experience in this region appeared in 1993 from Greece, while the other countries joined in from 2003 on. Up until 2019, the publication activity in this region was 16 and below publications per year when it rose to 33 (Fig. 2). The top five journals ranked by the number of articles in the analysed period are presented in Table 3.

The publications from countries with the highest publication activity, Greece, Romania and Croatia were further analysed regarding the author's gender, profession and country of origin. There were no differences between the countries regarding the gender of the first author, with $40.2 \%$ to $50 \%$ of first authors being female. The majority of the first authors, in all three countries, were physicians from the domicile country. The majority of senior authors in Croatia, Greece and Romania were male authors from the domicile country. The profession of the senior author differs significantly between the countries (Table 4 ).

Table 3. Top five journals ranked by number of publications until 2020

\begin{tabular}{lc}
\hline Top five journals by the number of publications & N \\
\hline Transplant Proceedings & 32 \\
\hline Chirurgia (Bucur) & 16 \\
\hline Journal of Gastrointestinal and Liver Diseases & 12 \\
\hline Liver Transplantation & 6 \\
\hline Transplantation Annals of Gastroenterology & 5
\end{tabular}

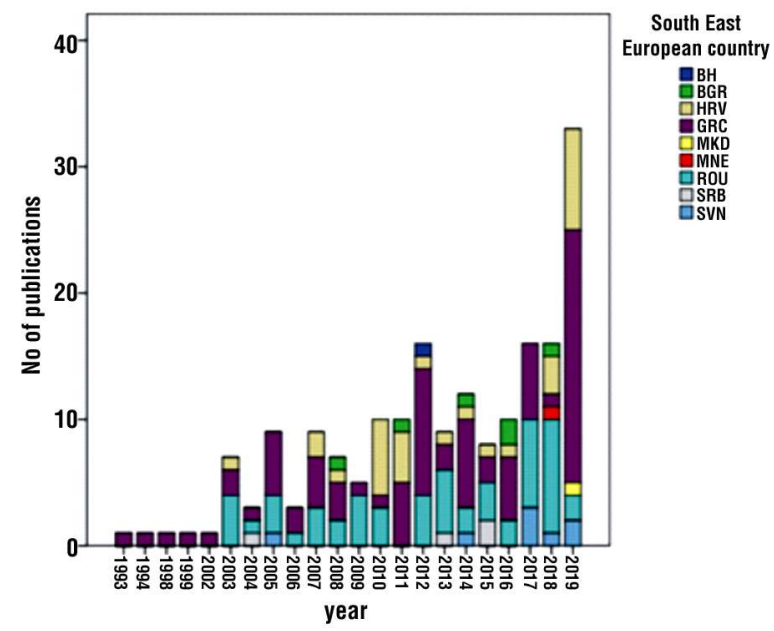

Figure 2. Publication activity on liver transplantation in SEE countries according to the year of publication (BIH - Bosnia and Herzegovina; BGR- Bulgaria; HRVCroatia; GRC - Greece; MKD- Montenegro; MNE North Macedonia; ROU - Romania; SRB - Serbia; SVN - Slovenia)

\section{Discussion}

To the best of our knowledge, this is the first bibliometric analysis evaluating the output of LT publications from the SEE nations. In this analysis, we demonstrated that the number of publications on LT and especially of those focusing on the national experiences from the SEE region is modest. Despite sharing many geographical, historical and socio-cultural aspects, this is a highly heterogeneous group of countries, and our results also reflect these diversities.

Liver transplantation activity in SEE countries ranges from virtually non-existing or very low to very high, with yearly numbers of LT pmp varying from 0 to more than 30 (1). As expected, the countries with non-existing or very low-volume LT programs (Bosnia and Hercegovina, Albania, Kosovo, Serbia, Macedonia, Montenegro) also have low publication output in the field.

Three countries with the highest output in our study were Greece, Romania and Croatia. Publications on LT experience from Greece represented $43 \%$ of the publication activity from the SEE region until 2020. Furthermore, Greece is also the country with the highest 
Table 4. Distribution of first and senior author according to gender, profession and domicile country in publications on liver transplantation from the top three SEE countries

\begin{tabular}{|c|c|c|c|c|}
\hline & $\begin{array}{c}\text { Croatia } \\
\text { n (\%) }\end{array}$ & $\begin{array}{l}\text { Greece } \\
n(\%)\end{array}$ & $\begin{array}{c}\text { Romania } \\
\text { n (\%) }\end{array}$ & $p$ \\
\hline \multicolumn{5}{|l|}{ First author } \\
\hline Gender, female & $15(50.0)$ & $33(40.2)$ & $25(45.5)$ & 0.622 \\
\hline $\begin{array}{l}\text { Profession } \\
\text {-physician } \\
\text {-surgeon } \\
\text {-other }\end{array}$ & $\begin{array}{cl}18 & (60.0) \\
11 & (36.7) \\
1 & (3.3)\end{array}$ & $\begin{array}{l}43(52.4) \\
19(23.2) \\
20(24.4)\end{array}$ & $\begin{array}{c}25(45.5) \\
21(38.2) \\
9(16.4)\end{array}$ & 0.055 \\
\hline $\begin{array}{l}\text { Country } \\
\text {-domicile } \\
\text {-non-domicile }\end{array}$ & $\begin{array}{c}27(90.0) \\
3(10.0) \\
\end{array}$ & $\begin{array}{l}69(81.1) \\
13(15.9)\end{array}$ & $\begin{array}{c}50(90.9) \\
5(9.1) \\
\end{array}$ & 0.452 \\
\hline \multicolumn{5}{|l|}{ Senior author } \\
\hline Gender, female & $11(36.7)$ & $18(22.0)$ & $14(25.5)$ & 0.288 \\
\hline $\begin{array}{l}\text { Profession } \\
\text {-physician } \\
\text {-surgeon } \\
\text {-other }\end{array}$ & $\begin{array}{c}16(53.3) \\
14(46.7) \\
0(0)\end{array}$ & $\begin{array}{ll}43 & (52.2) \\
21 & (25.6) \\
18 & (22.0)\end{array}$ & $\begin{array}{c}22(40.0) \\
26(47.3) \\
7(12.7)\end{array}$ & 0.008 \\
\hline $\begin{array}{l}\text { Country } \\
\text {-domicile } \\
\text {-non-domicile }\end{array}$ & $\begin{array}{c}27(90.0) \\
3(10.0)\end{array}$ & $\begin{array}{l}65(79.3) \\
17(20.7)\end{array}$ & $\begin{array}{c}48 \text { (87.3) } \\
7(12.7)\end{array}$ & 0.275 \\
\hline
\end{tabular}

cumulative IF. Despite a low level of LT activity in recent years (1), Greek authors with their experience in LT were shown to be the most productive in the region. Several factors may have been responsible. First of all, Greece has the longest tradition in LT in the region with the first LT performed in 1992 (5). Also, despite being hardly hit by the economic crisis and having undertaken significant cuts in health spending, Greece still has the second- highest per capita gross domestic product (GDP) among the studied countries, and the second-largest research and development expenditure relative to the national GDP, Table 5(6,7). Clinical research is an expensive and logistically complex process in any country, and both national GDP and research spending are known to correlate with publication activity $(4,8)$ positively. Thirdly, Greece was by far the first of the SEE countries to join the

Table 5. Gross domestic product, research spending and English proficiency of study nations $(7,9)$

\begin{tabular}{lccccc}
\hline COUNTRY & $\begin{array}{c}\text { Per capita } \\
\text { GDP (USD) } \\
\mathbf{2 0 1 8}\end{array}$ & $\begin{array}{c}\text { Research } \\
\text { spending } \\
\text { (\% GDP) }\end{array}$ & $\begin{array}{c}\text { Research } \\
\text { spending } \\
\text { rank }\end{array}$ & $\begin{array}{c}\text { TOEFL scores } \\
\mathbf{2 0 1 7}\end{array}$ & TOEFL rank \\
\hline Albania & $5,268.8$ & $0.15(2008)$ & 10 & 81 & 11 \\
\hline Bosnia and Hercegovina & $6,065.7$ & $0.20(2018)$ & 9 & 88 & 6 \\
\hline Bulgaria & $9,272.6$ & $0.75(2017)$ & 5 & 91 & 3 \\
\hline Croatia & $14,909.7$ & $0.86(2017)$ & 4 & 90 & 5 \\
\hline Greece & $20,324.3$ & $1.13(2017)$ & 2 & 93 & 1 \\
\hline Kosovo & $4,302.3$ & $\mathrm{~N} / \mathrm{A}$ & $\mathrm{N} / \mathrm{A}$ & 82 & 10 \\
\hline Montenegro & $8,844.2$ & $0.32(2016)$ & 8 & 83 & 9 \\
\hline North Macedonia & $6,083.7$ & $0.36(2018)$ & 7 & 87 & 7 \\
\hline Romania & $12,301.2$ & $0.50(2017)$ & 6 & 91 & 3 \\
\hline Serbia & $7,246.7$ & $0.92(2018)$ & 3 & 87 & 7 \\
\hline Slovenia & $26,124.0$ & $1.86(2017)$ & 1 & 93 & 1
\end{tabular}


European Union in 1981, more than 25 years before the other countries in the region, which inevitably facilitated the work migration of medical specialists leading to the promotion of scientific exchange, cooperation and publication. Finally, examinees from Greece (and Slovenia) show the best Test of English as a Foreign Language (TOEFL) performance among the study nations (9). It is well recognised that English proficiency is associated with better publication output (4).

Romania ranked second both in the number of publications and cumulative IFs. The per capita number of LT performed in the country is similar to the one in Greece. However, the abovementioned factors including GDP, research spending and English proficiency are in favour of Greece, and they may have influenced this more modest output. Croatia is the country with the highest LT activity in the region and also one of the countries with most LT performed pmp in the world (1). However, this was not shown to be reflected in the publication output. There are several possible explanations including low national spending on research (7), relatively short history of high volume LT in the country $(10,11)$, and high emigration rates of medical specialists since joining the European Union in 2013 (12) straining the remaining medical workforce with the clinical work. Previous research has also shown that high LT activity in a country does not always positively correlate with the publication output in the field (13).

The quality of journals has been historically assessed through "impact factors," often calculated as gross journal citation counts per number of manuscripts published over the past two years. Although citation counts are an imperfect measure of the performance, they are generally well accepted as a method of measuring journal/article impact and their exposure (14). Liver transplantation is a specific and narrow field, which consequently defines and limits a spectrum of potential journals. Namely, the size of the field, among other contributors, impacts the IF (potential authors citing a manuscript)(15,16). Therefore, many issues addressed in LT manuscripts may be too specific for a large community. On the other hand, the general surgery community is larger, and the interest is broader. The majority of publications from Greece, Romania and Croatia were published in journals with lower or non-existing IFs such as Transplant Proceedings, Chirurgia (Bucur) and Journal of Gastrointestinal and Liver Diseases reflecting the impact of the research.

Our analysis demonstrated that in Greece, Romania and Croatia physicians as the first authors are more productive than surgeons in publications dealing with LT. The often mentioned excuse that operative obligations prevent surgeons from publishing is not substantiated in other European countries. Schwarter et al. compared publication activity in cardiac surgery, general surgery and cardiology showing that the number of publications in German universities is a function of the number of academic personnel and not of the discipline (17). Data on gender representation in traditionally masculine specialities such as surgery show that female representation in publications is still low, although the gender gap is narrowing. Previous studies reported the increase of female first and senior authors in journals over the last decade, although the senior increase was significantly slower $(18,19)$.

Interestingly, in contrast to other research in hepato-pancreato-biliary surgery where women as first authors remain underrepresented (18), $40.2-50 \%$ of first authors in LT publications from the three SEE countries were female researchers. Nevertheless, the majority of them were physicians. As in the study by Farooq et al., the senior authors in our study were predominantly male researchers $(63.3-88 \%)$, but their profession (physician, surgeon, or other) varied significantly between the countries.

Our study has limitations that should be addressed. The profession of the authors has been extracted from the first affiliation and may not reflect the real profession. For example, some physicians may be employed at transplantation units and classified as surgeons. Some researchers' names have been 
listed by initials only, and they were tracked back to their institutions from which the gender was deducted.

\section{Conclusions}

In conclusion, the overall publication activity on LT from the SEE region is modest. The authors of Greece are the most productive in the region. We found that high liver transplantation activity does not necessarily translate into high publication output in the field. Despite the limitations of the study, we believe that this bibliometric analysis provides a valuable insight into the relatively unknown publication activity from the SEE nations, where it is critical to understand the nature of factors that influence the research and impact the quality of published articles. These data should prompt liver transplant communities in the SEE countries to address the need and find the solutions in order to increase research along with the quantity and quality of the publication output.

Funding information: No funding.

\section{Conflict of interest statement}

All authors declare no conflict of interest.

\section{References}

1. International registry for organ donation and transplantation. Available from: http://www.irodat.org/ [accessed 2020 the 21st of Aprill]

2. Nelkin D. Publication and promotion. The performance of science. Lancet. 1998;352(9131):893.

3. Horton R. Publication and promotion. A fair reward. Lancet. 1998; 352(9131):892
4. Man JP, Weinkauf JG, Tsang M, Sin DD. Why do some countries publish more than others? An international comparison of research funding, English proficiency and publication output in highly ranked general medical journals. Eur J Epidemiol 2004;19(8): 811-817

5. Xinias I, Mavroudi A, Vrani O, Imvrios G, Takoudas D, Spiroglou K. Liver transplantation in Greek children: 15 years experience. Pediatr Rep 2010;2(2):e14

6. Giorgakis E, Singer AL, Khorsandi SE, Prachalias A. Transplantation crisis at the time of economic recession in Greece. Public Health. 2018:160:125-128.

7. The World Bank. Available from: https://data.worldbank.org/ [accessed 2020 the 23rd of April]

8. Nathan DG. Clinical research: perceptions, reality, and proposed solutions. National Institutes of Health Director's Panel on Clinical Research. JAMA. 1998;280(16):1427-31.

9. Test of English as a Foreign Language. Available from: https://www. ets.org/s/toefl/score_data_summary [accessed 2020 the $22^{\text {nd }}$ of April]

10. Eurotransplant. Available from: https://www.eurotransplant.org/ [accessed 2020 the $29^{\text {th }}$ of April]

11. Croatian Ministry of Health. Croatian. Available from: https://zdravlje.gov.hr/nacionalni-transplantacijski-program/1528 [accessed 2020 the $29^{\text {th }}$ of April]

12. Croatian Medical Chamber. Croatian. Available from: https://www.hlk.hr/ [accessed 2020 the 29th of April]

13. Bas K, Dayangac M, Yaprak 0 , Yuzer $Y$, Tokat $Y$. International collaboration of Turkey in liver transplantation research: a bibliometric analysis. Transplant Proc 2011;43(10):3796-801

14. Mullins $\mathrm{CH}$, Boyd CJ, Lindeman B. Factors Associated With the Highest and Lowest Cited Research Articles in General Surgery Journals. J Surg Res. 2020;250:39-44. Epub 2020 Jan 31.

15. Slyder JB, Stein BR, Sams BS, et al. Citation pattern and lifespan: a comparison of discipline, institution, and individual. Scientometrics 2011:89:955-966

16. Castellano C, Radicchi F. On the fairness of using relative indicators for comparing citation performance in different disciplines. Arch Immunol Ther Exp (Warsz) 2009;57(02):85-90

17. Schwarzer M, Alscher L, Doenst T. Comparison of Scientific Publications from Three Different Clinical Disciplines of German Universities. Thorac Cardiovasc Surg 2019:67(6):488-493

18. Farooq A, Sahara K, Muneeb A, Farooq K, Tsilimigras DI, Merath K, et al. Analysis of Authorship in Hepatopancreaticobiliary Surgery: Women Remain Underrepresented. J Gastrointest Surg. Epub 2019 Aug 8.

19. Filardo G, da Graca B, Sass DM, Pollock BD, Smith EB, Martinez MA. Trends and comparison of female first authorship in high impact medical journals: observational study (1994-2014). BMJ 2016;352:1847

20. Welsh TS. Qualitative and quantitative methods in libraries journal special issue: Bibliometrics and scientometrics. Qual Quant Methods Libr 2017:5:1-3 